\title{
Distribution of Water Infiltration Rate in Ciliwung Watershed
}

\author{
Irfan B. Pramono \\ Watershed Management Technology Center \\ Corresponding author (email: ibpramono@yahoo.com)
}

\begin{abstract}
Floods in Jakarta showed that the Ciliwung watershed and surrounding areas in critical condition. More than $50 \%$ of land cover Ciliwung watershed is residential. Planting trees in residential areas have been insufficient to infiltrate as much water into the ground. Infiltration well is one possibility for absorbing water in residential areas. The purpose of this study was to determine the variation in the level of water absorption Ciliwung watershed and surrounding areas. The method used is overlaying analysis of the factors that determine the rate of water infiltration with geographic information system. Each of these factors gave weights and scores to obtained variations Ciliwung water infiltration rate. The results showed that the regions with the highest levels found in the upper catchment area and the city of Bogor, middle absorbtion water area was in Bogor Regency, low water absorption areas in Depok, South Jakarta, and East Jakarta . While in North Jakarta, Central Jakarta and West Jakarta the water absortion is very low level due to the shallow ground water level and very low soil permeability. Map variations in water absorption can be used as a material consideration for determining the locations of recharge wells effectively.
\end{abstract}

Keywords: Flood, recharge area, infiltration wells

\begin{abstract}
Abstrak
Banjir yang rutin terjadi di Jakarta menunjukkan bahwa DAS Ciliwung dan sekitarnya dalam kondisi kritis. Lebih dari 50\% penutupan lahan DAS Ciliwung adalah permukiman dengan tipe rumah dan luas tanah yang rata-rata sempit. Penanaman pohon di areal permukiman sudah tidak memadai untuk meresapkan air ke dalam tanah karena hampir seluruh lahan digunakan untuk bangunan. Salah satu yang masih memungkinkan adalah pembuatan sumur resapan, namun perlu mempertimbangkan tingkat resapan airnya. Tujuan penelitian ini untuk mengetahui sebaran tingkat peresapan air di DAS Ciliwung dan sekitarnya. Metode yang digunakan adalah analisis tumpang susun faktor-faktor yang menentukan tingkat peresapan air dengan sistem informasi geografi. Masing-masing faktor penentu peresapan air diberi bobot dan skor sehingga diperoleh variasi tingkat peresapan air DAS Ciliwung. Hasilnya menunjukkan bahwa daerah yang mempunyai tingkat peresapan tertinggi terdapat di daerah Puncak dan Kota Bogor, daerah peresapan sedang di Kabupaten Bogor, daerah peresapan air rendah di Kota Depok, Jakarta Selatan, dan Jakarta Timur. Adapun wilayah Jakarta Utara, Jakarta Pusat, dan Jakarta Barat tingkat peresapannya sangat rendah karena ketinggian muka air tanahnya dangkal. Peta variasi peresapan air ini dapat digunakan sebagai salah satu bahan pertimbangan untuk menentukan lokasi-lokasi pembuatan sumur resapan yang efektif.
\end{abstract}

Kata kunci: Banjir, peresapan air, sumur resapan

\section{Introduction}

Floods in Jakarta grew bigger with the increasing impact of losses. Floods in Jakarta in 2002 caused losses of Rp. 9.8 trillion, while floods in 2007 and 2013 respectively cause harm Rp.5,16 trillion and Rp 20 trillion (Ratnaningsih, 2013). Flooding is mainly caused by two things: the supply of high water from upstream areas and the lack of channels and inadequate drainage in the downstream areas. Handling of downstream flooding is needed to cope with the flood quickly.
However, the increase in the downstream drainage capacity will never be sufficient if the upstream area is not addressed, particularly in improving water infiltration.

Harisuseno et al. (2014) suggested that the parameters that affect the value of runoff is the rainfall intensity, land use and soil type. Surface runoff will be reduced by drainage channels with good and adequate capacity. Flooding occurs because the drainage channels are not able to accommodate the discharge 
of runoff. Rahmat and Pamungkas (2014) in their study in Makassar concluded that the vulnerability factor influencing flooding is inadequate drainage conditions, the location of settlements in the accumulation of puddles, and decrease in soil infiltration.

Land cover of Ciliwung watershed is dominated by settlements (Pramono et al. 2013). Existing settlements are not like a yard where there are still parts of vegetation to absorb water, but dense settlements in which nearly all the surface is covered by a layer of impermeable so that there is no place for rainwater to infiltrate into the ground. Boggs and the Sun (2011) compared the hydrological characteristics of the watershed urban $(44 \%$ of the land covered housing) and wooded watershed in North Carolina (99\% forest), rainfall during the study in both locations is almost the same, namely $376 \mathrm{~mm}$ and $389 \mathrm{~mm}$ respectively for urban and forested watershed, the results show that the runoff coefficient for urban watershed of 0.42 and 0.24 forested watershed. Urban watershed flood peak at $76,6 \mathrm{~mm} /$ day and in a forested watershed 5.8 $\mathrm{mm} /$ day. Green Open Space (RTH) in urban areas is also capable reduces runoff coefficient (Fatima et al., 2011). Conversely, an increase in residential area in the catchment areas resulted in decreased water level of wells and increase runoff by $37.5 \%$ in Gunungpati, Semarang (Dewi \& Rudiarto, 2014)

Low water absorption causes the groundwater reserves to be greatly reduced as observed in hydrological station Katulampa, Bogor, and hydrological station Sugutamu, Depok. Whereas the groundwater availability is important to supply domestic needs (Jumadi \& Priyana, Y., 2015). Groundwater flow (base flow) in both stations decreased significantly over the last 30 years (Subagyono \& Pawitan 2008). Pancawati (2013) mentions that the water catchment land required to meet the needs of clean water for residents of Tangerang City is 589444 ha, while the condition of green open land area of only 7,705 ha.
Resettlement areas in Ciliwung occupies the largest share, ie $51.53 \%$ of the watershed area. Going forward, the greater comprehensive settlement in line with population growth in the Greater Jakarta area. Dewi (2011) says there are four factors that need to watch the issue of settlements in Sub Ciliwung Hulu namely, 1) the settlement developed very fast, 2) land degradation, 3) high population growth, and 4) implementation of spatial inconsistent with Areal Space in Regional Planning (RTRW). These conditions have potential to enlarge flood in Jakarta. Singgih (2000) in Pawitan (2002) said that the settlement in the Upper Ciliwung from 1981 to 1999 rose $98.82 \%$, while in the same period in the Middle Ciliwung, the settlement rose $70.94 \%$. The impact of land use change cause increasing the Ciliwung upstream discharge by $68 \%$ and 24\% Middle Ciliwung (Pawitan, 2002). Furthermore Pawitan (2002) concluded that the appropriate land management in Ciliwung upstream can control discharge and volume of downstream flooding.

In order to overcome the floods in Jakarta, Jakarta Provincial Government through regional cooperation forum main civil partners provide grants to regions upstream, including the Bogor Regency Rp. 5 billion for watershed handling (Anonymous, 2013). The grants are used among others for building infiltration wells in Bogor, expecting to reduce the flooding that occurred in Jakarta. As catchment wells in dense residential area is one of the solutions to reduce the supply of water flooding (Subagyono \& Pawitan 2008; Joga, 2009; Fakhrudin 2010; Pramono, 2013). In addition, recharge wells can function increase groundwater recharge (Purnama et al., 2006 and Samsuhadi, 2009).

Each location has a different ability to absorb water, therefore the effectiveness of recharge wells depending on site conditions and its ability to absorb water. Water catchment area is a place where rain water can get into the soil and then fill or replenishes groundwater. The 
ability to absorb water in the soil is influenced by several factors, including the type of rock, soil texture, slope, rainfall factor, and the depth of the ground water level (Wibowo 2006). In order for grant administration to meet the construction of recharge wells and measurable targets in reducing flooding in Jakarta, it is necessary for mapping the distribution of water infiltration rate in Ciliwung and its surroundings. This study aims to identify the distribution map of water infiltration rate in Cilwung watershed and surrounding areas that contribute for flooding in Jakarta. From the map it can be seen: 1). areas that are most able to absorb water, 2). locations are prioritized for making of recharge wells. This information is expected through the allocation of aid from Jakarta can be more proportionally to the rate of water absorption.

\section{Research Method}

The study was conducted in 2013. The research locations covering the entire watershed Ciliwung and its surrounding such as watershed of Angke, Cakung, Krukut, Pesanggrahan, Buaran, and Sunter. Land cover map of Ciliwung watershed can be seen

in Figure 1.

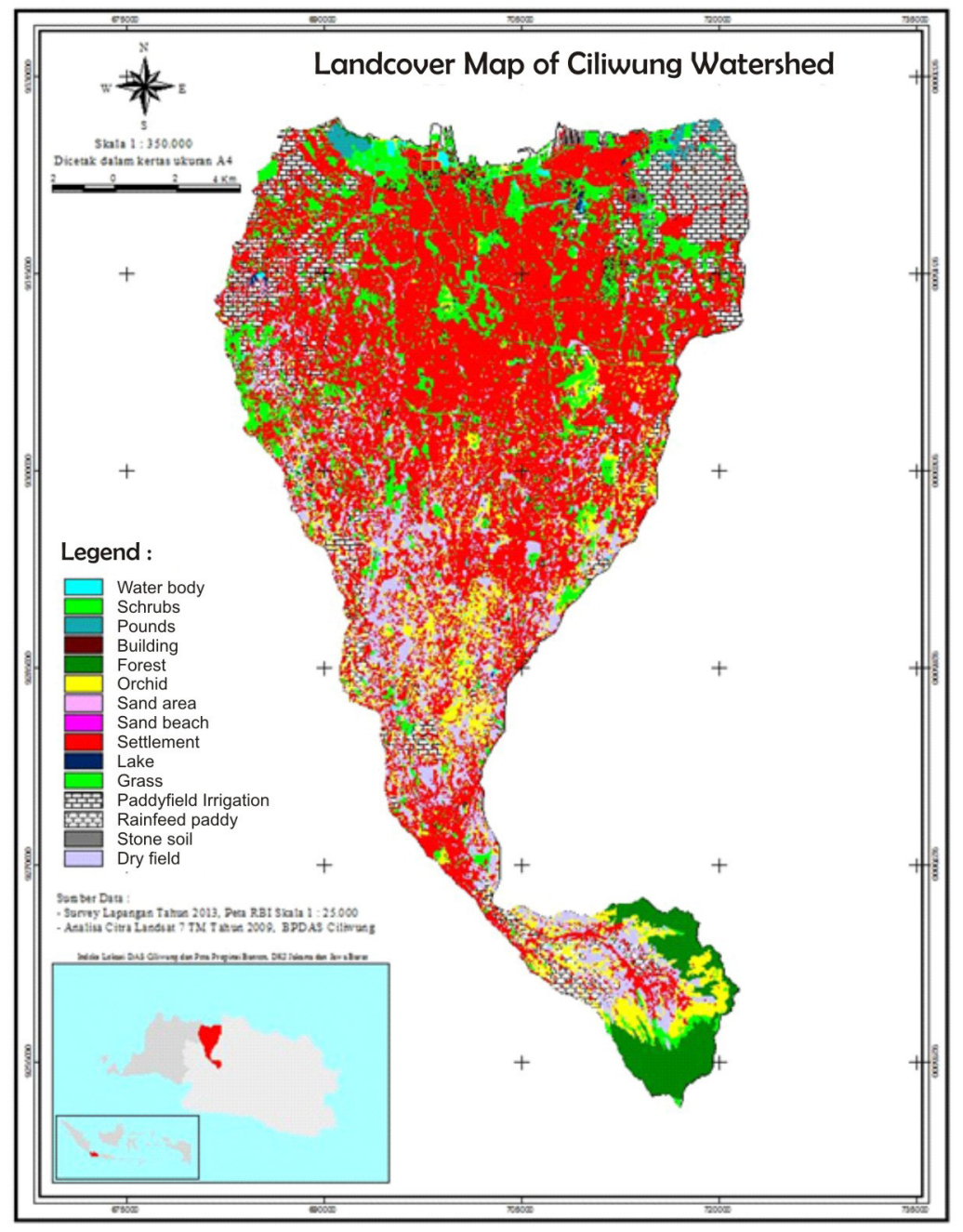

Source: Landsat image interpretation on 2011

Figure 1. Land cover map of Ciliwung Watershed

The method used is overlaying analysis of the factors that determine the rate of water infiltration with geographic information system. Each of these factors gave weights and scores to obtained variations Ciliwung water infiltration rate. Factors influencing water 
infiltration rate are rock types, rainfall, soil texture, slope, and depth of the groundwater. Each factor is given a score and weighting then overlaid using Geographical Information Systems. The level of water infiltration derived from combining these factors. Table 1 shows the weight values of each parameter (Wibowo, 2006). The Highest weighting given to the parameters that the most influence on water infiltration.

Table 1. Weight of water infiltration parameters

\begin{tabular}{clcl}
\hline No & Parameter & Weight & \multicolumn{1}{c}{ Category } \\
\hline 1 & Rock type & 5 & very high \\
2 & Rainfall & 4 & High \\
3 & Soil texture & 3 & Moderate \\
4 & Slope steepness & 2 & Low \\
5 & $\begin{array}{l}\text { Depth of water } \\
\text { table }\end{array}$ & 1 & very low \\
\hline
\end{tabular}

\section{Rock Types}

Rock type data are obtained from the Geologic Map Jakarta Scale 1: 250,000. Distribution of scores on each type of rock can be seen in Table 2. The type of rocks that have high permeability has a high score.

Table2. Score of rock types

\begin{tabular}{clcc}
\hline No & \multicolumn{1}{c}{ Rock type } & Score & Category \\
\hline 1 & alluvial deposits & 5 & very high \\
2 & $\begin{array}{l}\text { young sediments } \\
\text { quarter }\end{array}$ & 4 & High \\
3 & $\begin{array}{l}\text { old sediments } \\
\text { quarter }\end{array}$ & 3 & Moderate \\
4 & tertiary sediments & 2 & Low \\
5 & instrusive rocks & 1 & very low \\
\hline Source: Wibowo (2006) & &
\end{tabular}

\section{Rainfall}

The intensity of the rain effect on the rate of water infiltration. High intensity rainfall will absorb less water than the rain at low intensity. To assess the value of the requested amount of rainfall and rainy days with the following formula:
$\mathrm{FH}=0.01 * \mathrm{P} * \mathrm{HH}$

Where :

FH : Rainfall factor

$\mathrm{P} \quad$ : Rainfall (mm)

HH : Rainy Day (day)

The division of the rain factor scores are presented in Table 3.

Table 3. Score of rainfall

\begin{tabular}{cccl}
\hline No & $\begin{array}{c}\text { Rainfall } \\
\text { factor }\end{array}$ & Score & \multicolumn{1}{c}{ Category } \\
\hline 1 & $>5,550$ & 5 & very high \\
2 & $4,625-5,550$ & 4 & High \\
3 & $3,700-<$ & 3 & Moderate \\
& 4,625 & & \\
4 & $2,775-<$ & 2 & Low \\
& 3,700 & & very low \\
\hline
\end{tabular}

Source: Wibowo (2006)

\section{Soil Texture}

Soil texture affect the rate of water infiltration. The rough texture like sand will absorb more water than that loam soil texture. Distribution of scores soil texture can be seen in Table 4 .

Table 4. Score of soil texture

\begin{tabular}{clcl}
\hline No & Soil texture & Score & \multicolumn{1}{c}{ Category } \\
\hline 1 & very rough & 5 & very high \\
2 & rough & 4 & High \\
3 & moderate & 3 & Moderate \\
4 & fine & 2 & Low \\
5 & very fine & 1 & very low \\
\hline
\end{tabular}

\section{Slope Steepness}

The smaller the slope of an area, the greater the chance of water infiltrate into the ground so that the flat area of highest water permeability rate, and vice versa in areas with high slopes will have a low level of water infiltration. The scores and grade of slope can be seen in Table 5 
Table 5. Score of slope steepness

\begin{tabular}{cccl}
\hline No & $\begin{array}{c}\text { Slope } \\
\text { steepness }\end{array}$ & Score & \multicolumn{1}{c}{ Category } \\
\hline 1 & $<8$ & 5 & very high \\
2 & $15-8$ & 4 & High \\
3 & $>15-25$ & 3 & Moderate \\
4 & $>25-45$ & 2 & Low \\
5 & $>45$ & 1 & very low \\
\hline Source: Wibowo (2006) & &
\end{tabular}

\section{Groundwater Depth}

The greater the depth of the ground water level, the greater its ability to absorb water. Scores depth of ground water level can be seen in Table 6 .

Table 6. Score of ground water level

\begin{tabular}{cccc}
\hline No & $\begin{array}{c}\text { Water table } \\
\text { depth }\end{array}$ & Score & Category \\
\hline 1 & $>30$ & 5 & very high \\
2 & $>20-30$ & 4 & high \\
3 & $>10-20$ & 3 & moderate \\
4 & $>5-10$ & 2 & low \\
5 & $<5$ & 1 & very low \\
\hline Source: Wibowo (2006) & &
\end{tabular}

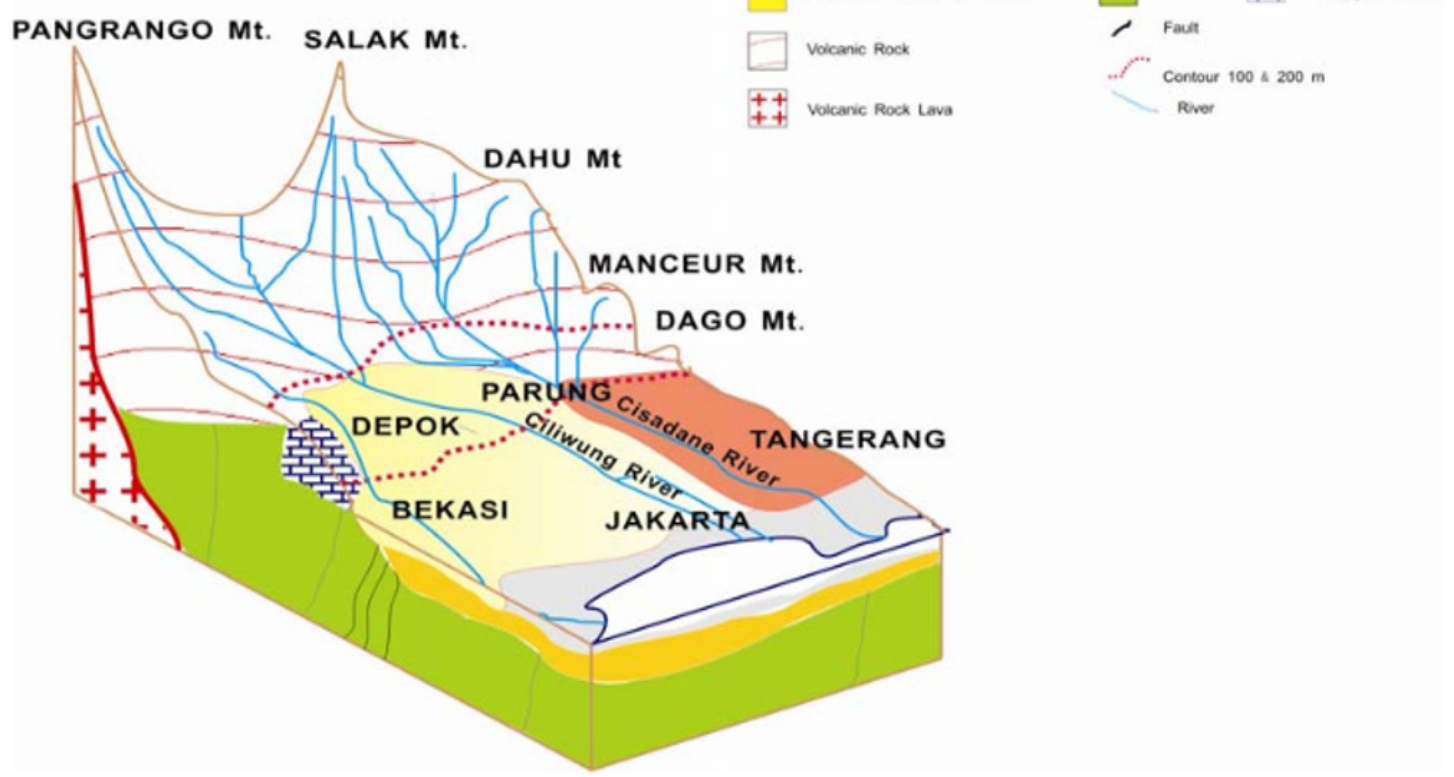

Source : Delinom, 2010.

Figure 2. Geological cross section in Jakarta and its surrounding area
The depth of the groundwater table was obtained from secondary data and direct measurements in the field. Direct measurement is done by measuring the depth of the well from upstream to downstream. The level of water infiltration is determined by summing the multiplication of weight (Table 1) and score (Table 2 to Table 6). Geographical Information Systems (GIS) is used to analyze water infiltration level spatially. The overlaying of water infiltration level map and administration map can be produced map of distribution water infiltration level in Ciliwung watershed.

\section{Results}

\section{Rock Types}

Based on the Geological Map Scale 1:250,000 Sheet Jakarta (Effendi et al. 1998), the rock types in Ciliwung consist of alluvial deposits spread downstream and river banks, while the type of rock in the middle of the Ciliwung is precipitated quarter. Upstream of Ciliwung dominated by Tertiary sediment and intrusive rocks fraction. Geological cross sections in Jakarta and surrounding areas can be seen in Figure 2.

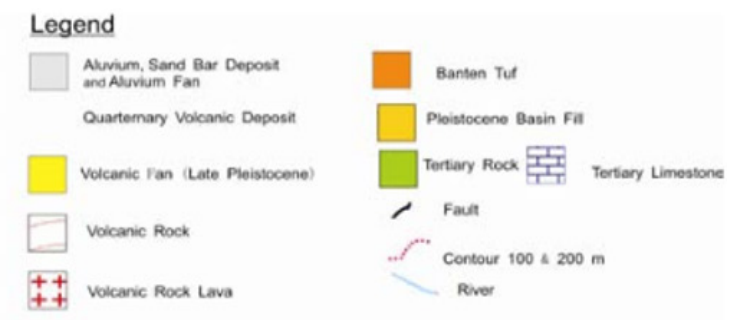




\section{Rain Factor}

Rain factor is mapped Thiessen Polygon method. Based on the registration of rain in the downstream (rain station Cawang), in the middle (rain station Depok), and upstream (Bogor and Puncak rain station) then rain in Ciliwung included in the score 3 to 5 by a factor of rainfall ranges various from 3700 to 5550 .

\section{Soil Texture}

The soil texture in Ciliwung watershed is dominated by fine texture that spread in the middle. The soil texture in the upstream Ciliwung was coarse and downstream has a fine texture that is clay sediment along the coast bordering the rough textured.

\section{Slopes}

Slope in Ciliwung watershed is dominated by flat slope $(<8 \%)$ spread downstream, while in the midlle area has a slope ranging from 8 to $15 \%$. The steep slopes only occurred in the upstream.

\section{Groundwater Depth}

The depth of the ground water level in Ciliwung very varied. In general, the more upstream depth of the ground water level to deepen. However, at certain points there is a distorted caused by the aquifer-local aquifer or perched aquifer in these places. Perched aquifer is an aquifer that is above the groundwater level the main or regional ground water table. Perched aquifer occurs because there impermeable layer above the main ground water level. In the downstream area of the well depth of less than five meters, while in the central area has a large range ranging from five to $30 \mathrm{~m}$ and in the upstream face of the groundwater depths up to more than $30 \mathrm{~m}$.

\section{The Rate of Water Infiltration Ciliwung Watershed And its Surrounding Area}

Based on the analysis of overlaying spatial data on the types of rock, soil texture, rainfall, slope, and depth of the ground water level has been given a weight and then obtained a score Watershed map as shown in Appendix
1. From Appendix 1 can be seen that the area has a very high permeability spread in the city of Bogor and upper area. As for having a high permeability rate spread in Bogor District. The level of permeability of water being dispersed in Depok, South Jakarta and East Jakarta. In North Jakarta and West Jakarta has a low permeability rate for the depth of ground water table is shallow. Although the permeability in the upstream is highest, the infiltration rate is not highest due to steep slope. The water has little time to infiltrate in the soil. By contrast, in the city of Bogor with permeability lower than at the upper watershed (Puncak), but the infiltration is higher because the area is flat.

\section{Discussion}

There are some parameters for identification of groundwater recharge. Preeja et al.,(2011) proposed 7 parameters such as land cover, drainage density (Dd), lineament density, soil, slope, geomorphology, and lithology. Kaliraj et al.(2014) proposed 11 parameters such as lineament, slope, soil permeability, soil texture, soil depth, geomorphology, geology, drainage, land cover, aquifer, and annual rainfall. While Chacahadi (2015) gave 6 parameters namely slope, aquifer specific yield, land cover, depth of groundwater table, surface geology, and topography. Furthermore, Yeh et al,(2016) gave 5 parameters for identification of groundwater recharge namely lithology, land cover, lineament, Dd, and slope. Based on the previous research there are many parameters for determining groundwater recharge, but some parameters can be grouped. Lineament, Dd, geology, and aquifer, for example, can be grouped as rock type. Soil permeability, soil texture, and soil depth can be grouped as soil type.

Important parameter such as water table did not mentioned by the researchers. Water table parameter is simple and an insensitivity to the mechanism by which water moves through the unsaturated zone (Healy and Cook .2002). Chacahadi (2015) also mentioned that water table is one of 6 parameters for identification of groundwater recharge. Therefore, water 
table is important parameter for identification of groundwater recharge.

Parameters such as slope and rainfall are also important parameters and these parameters are used by the researchers. Kaliraj et al. (2014) used annual rainfall while Thomas et al.(2016) mentioned that groundwater recharge is influenced by rainfall intensity. In order to simplify parameter, the research uses the most important parameter such as slope, rainfall, rock type, soil texture, and water table depth. The results of the analysis of water infiltration rate in the catchment areas are almost same to as the results of Fakhrudin (2010), except for the catchment areas in the Middle Ciliwung. His research concluded that the rate of declining infiltration wells in the Upper, Middle, and Lower respectively by 0.94 to $1.14 \mathrm{~cm} / \mathrm{min}$, 0.63 to $0.64 \mathrm{~cm} / \mathrm{min}$, and 0.24 to $0,43 \mathrm{~cm} /$ min.

Based on the results overlay as seen in Figure 9, the most effective absorption wells (the highest absorption rate) is located in the city of Bogor. In the city of Bogor very likely developed infiltration wells because the area is a residential area and the topography is relatively flat. The capacity of absorption wells per $100 \mathrm{~m} 2$ plots in the city of Bogor can be made with a volume of $3 \mathrm{~m} 3$. Water conservation for the summit area need a combination of infiltration wells and water trap for forests, ponds for agricultural areas. For the city of Depok, South Jakarta and East Jakarta, which has a water infiltration rate lower, water conservation, can be done by making the recharge wells but with volume sizes larger than in the city of Bogor. Revitalization lakes need to be done in the area of Depok, South Jakarta and East Jakarta. While the area of Central Jakarta, North Jakarta and West Jakarta are less suitable for absorption well due to lower infiltration rate and the depth of ground water table is relatively shallow.

\section{Conclusions}

- The regions that have a large degree of permeability distribute from upper watershed (Puncak) to the city of Bogor. Depok City, East Jakarta, and South Jakarta has a lower permeability rate, whereas in Central Jakarta, North Jakarta and West Jakarta has the lowest rate of permeability.

Water conservation by infiltration wells are very suitable to be applied in the city of Bogor and Puncak. Application of recharge wells to Kota Depok, South Jakarta and East Jakarta needs to be made with a larger capacity than the absorption wells made in the city of Bogor and Puncak.

- Advantages of recharge wells in addition to reducing flooding can also increase soil water reserves. The economic value of soil water reserve additions need to be taken into account so that the cost of making infiltration wells more economical.

- Cooperation between districts and between provinces should be improved to cope with flooding in Jakarta. Map of water infiltration can be used to determine the allocation of aid from downstream to upstream areas.

\section{References}

Anonim. (2013). Ahok : Hibah Rp. 5 milyar ke Bogor mungkin kurang. KoranTempo 30 Oktober 2013.

Boggs, J.L. \& Sun, G.(2011). Urbanization alters watershed hydrology in the Piedmont of North Carolina. Ecohydrology 4: 256-264

Chachadi, A.G. 2015. New indicators based method SALDIT for delineation of natural groundwater recharge area. Aquatic Procedia 4: 649-659 on International Conference on Water Resources, Coastal, and Ocean Engineering. 
Delinom, R.M. (2010). Geology and hydrogeology of Ciliwung watershed in integrated watershed management for sustainable water use in a humid tropic tropical region. Bulletin of the Terrestrial Environment Research University of Tsukuba 10 (Supplement No.1): 27-34.

Dewi, I.K. (2011). Faktor-faktor yang berpengaruh terhadap keberlanjutan kawasan pemukiman di DAS Ciliwung Hulu, Kabupaten Bogor. J.Ekologia 11(1): 12-20.

Dewi, N.K. \& Rudiarto, I. (2014). Pengaruh konversi lahan terhadap kondisi lingkungan di wilayah Peri-urban Kota Semarang (Studi kasus: Area berkembang Kecamatan Gunungpati). J. Pengembangan Wilayah dan Kota 10 (2): 115-126.

Effendi, A.C., Kusnawa \& Hermanto, B. (1998). Peta geologi daerah Bogor, Jawa, Indonesia. Puslitbang Geologi Bandung, Indonesia

Fakhrudin, M. (2010). Kajian sumur resapan sebagai pengendali banjir dan kekeringan di Jabodetabek. J.Limnotek 17 (1) : 8-16. Limnologi LIPI.

Fatimah, I.S., Munandar, A. Sinukaban, N. \& Kolil. (2011). Aplikasi program analisis Citygreen 5.4 untuk kajian ruang terbuka hijau $(\mathrm{RTH})$ dan manfaat layanan tertentu ekosistem Kota Bogor. Ekologia 11 (1): 1-11.

Harisuseno, D., Bisri, M., Yudono, A. \& Purnamasari, F.D. (2014). Analisa spasial limpasan permukaan menggunakan model hidrologi di wilayah perkotaan. J. Environmental Engineering \& Sustainable Technology 1 (1): 51-57

Healy, R.W. \& P.G.Cook.2002. Using groundwater levels to estimate recharge. Hydrogeology Journal 10 (1): 91-109

Joga, N. (2009). Ekspedisi Ciliwung. Laporan Jurnalistis Kompas. Mata Air. Air Mata.Gramedia.

Jumadi, J., Priyana, Y., 2015. Development and Evaluation of Web GIS Application for Groundwater Management of Karanganyar Regency. Forum Geografi 29, 165-174.

Kaliraj, S., N.Chandrasekar, N.S. Magesh.2014. Identification of potential groundwater recharge zones in Vaigai upper basin, Tamil Nadu, using GIS-based analytical hierarchical processes (AHP) technique. Arab J. Geosciences 7 (4): 1385-1401

Pancawati, J. (2013). Ketersediaan lahan resapan air di Kota Tangerang. J. Ilmu Pertanian dan Perikanan 2 (1) : 11-18. Univ. Sultan Ageng Tirtayasa, Serang, Banten.

Pawitan, H. (2002). Hidrologi DAS Ciliwung dan andilnya terhadap banjir di Jakarta. Makalah disajikan dalam Lokakarya Pendekatan DAS dalam menanggulangi banjir Jakata, diselenggarakan oleh Lembaga Penelitian IPB bekerjasama dengan Andersen Consult, Jakarta, 8 Mei 2002.

Pramono, I.B. (2013). Cara alami atasi banjir Jakarta. Republika online 22 Januari 2013.

Pramono, I.B., Paimin, Basuki, T.M. \& Purwanto (2013). Kajian Aplikasi “Tipologi DAS" dalam Pengembangan sistem perencanaan pengelolaan DAS lintas propinsi. Laporan Hasil Penelitian BPTKPDAS Surakarta.

Preeja, K.R., S. Joseph, J.Thomas, H. Vijith.2011. Identification of groundwater potential zones of Tropical river basin (Kerala, India) using Remote Sensing and GIS techniques. J.Indian Soc.Remote Sensing 39 (1):83-94

Purnama, S., A Kurniawan, Sudaryatno. 2006. Model konservasi air tanah di daerah pantai Kota Semarang. Forum Geografi 20 (2): 160-174. 
Rahmat A.R. \& Pamungkas, A. (2014). Faktor-faktor kerentaan yang berpengaruh terhadap bencana banjir di Kecamatan Manggala Kota Makassar. J. Tehnik Ponits 3(2): 178-183

Ratnaningsih, M. (2013). Analisis dampak kerugian banjir di Jakarta. Diskusi Panel: Membumikan upaya mengatasi banjir Jakarta secara holistic dan terintegrasi. Yayasan Sarana Wana Jaya dan Ditjen BPDAS\& PS. Jakarta: 7 Mei 2013.

Samsuhadi. (2009). Pemanfaatan air tanah Jakarta. JAI. 5 (1): 9-22. Badan Pengkajian Penerapan Teknologi, Jakarta.

Subagyono, K. \& Pawitan, H. (2008). Water harvesting techniques for sustainable water resources management in the catchment area. Proceedings of International workshop on integrated watershed management for sustainable water use in a Humid Tropical Region. Bull. Univ. Tsukuba 8 (Supplement No. 2): 18-30.

Thomas, B.F., A.Behrangi, and J.S. Famigilietti. 2008. Precipitation intensity effects on groundwater recharge in the Southwestern United States. Water 8 (90):1-15

Wibowo, M. (2006). Model penentuan kawasan resapan air untuk perencanaan tata ruang berwawasan lingkungan. J. Hidrosfir 1(1): 1-7. Badan Pengkajian dan Penerapan Teknologi, Jakarta.

Yeh, H.F., Y.S. Cheng, H.I. Lin, and C.H.Lee. 2016. Mapping groundwater recharge potential zone using a GIS approach in Hualian river, Taiwan. Sustainable Environment Research 26 (1): 33-43. 

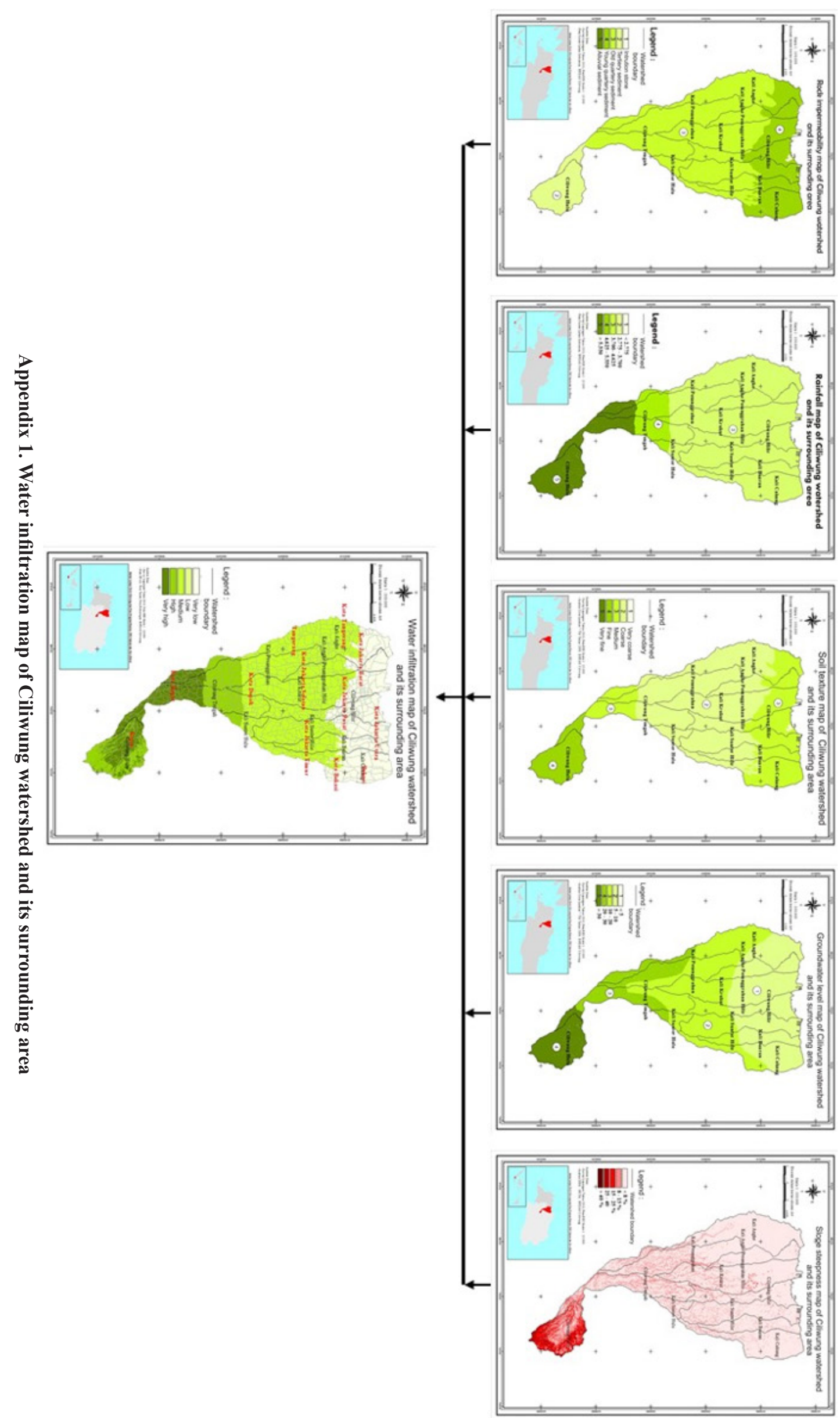

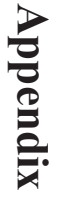

